\title{
Surgical technique of tunneling for gingival recession recovery - clinical case report
}

\author{
Técnica cirúrgica de tunelização para recobrimento de recessão gengival - relato de caso clínico \\ Técnica quirúrgica de túneles para la recuperación de recesión gingival - reporte de caso clínico
}

Received: 09/02/2021 | Reviewed: 09/10/2021 | Accept: 09/13/2021 | Published: 09/20/2021

\author{
Bruna Gabrielle Pereira Silva \\ ORCID: https://orcid.org/0000-0003-2792-0467 \\ Instituto Nacional de Ensino Superior e Pós-Graduação Padre Gervásio, Brazil \\ E-mail: dentistabrunapereira@ hotmail.com \\ Márcio Américo Dias \\ ORCID: https://orcid.org/0000-0002-6103-5878 \\ Instituto Nacional de Ensino Superior e Pós-Graduação Padre Gervásio, Brazil \\ E-mail: marcdias6@gmail.com \\ Rafael de Aguiar Vilela Júnior \\ ORCID: https://orcid.org/ 0000-0001-6312-6637 \\ Instituto Nacional de Ensino Superior e Pós-Graduação Padre Gervásio, Brazil \\ E-mail: rafaelvilelajr@yahoo.com.br
}

\begin{abstract}
Connective tissue graft associated with surgical tunneling technique has been cited as favorable option for the treatment of moderate. Miller class I and II gingival recession. This presente article aims to report a clinical case of a 43-yers-old male patient selected for the treatmente of gingival recession of tooth 41. After clinical and radiographic evaluation, we concluded that it was a Miller class I recession. It was decided to proceed surgically with the root coverage of this tooth using the tunneling technique. One month after the procedure, complete root coverage, no bleeding on probing depth of $3 \mathrm{~mm}$ and perfectesthetic integration with the with the adjacente tissues were observed. In view of the aforementioned case, it is clear that this technique presentes very predictable results When indicated and executed correctly, thus reaching a very aesthetic result.
\end{abstract}

Keywords: Gingival retraction; Oral surgery; Gingival retraction.

\section{Resumo}

O enxerto de tecido conjuntivo associado a técnica cirúrgica de tunelização, tem sido citada como uma opção favorável para o tratamento de recessões gengivais classe I e II de miller moderadas. Este presente artigo tem por objetivo relatar um caso clínico de um paciente de 43 anos, do seco masculino, selecionado para o tratamento de recessão gengival do dente 41. Após avaliação clínica e radiográfica, concluímos que se tratava de uma recessão classe I de Miller. Ficou decidido em proceder cirurgicamente com o recobrimento radicular desse dente recorrendo a técnica de tunelização. Após 1 mês do procedimento, observou-se recobrimento radicular completo, ausência de sangramento a sondagem, profundidade de sondagem de $3 \mathrm{~mm}$ e uma perfeita integração estética com os tecidos adjacentes. Diante do caso supracitado, fica claro que esta técnica apresenta resultados bastante previsíveis quando indicada e executada corretamente, chegando assim na obtenção de um resultado muito estético.

Palavras-chave: Retração gengival; Cirurgia bucal; Retração gengival.

\section{Resumen}

El injerto de tejido conectivo associado com la técnica de tunelización quirúrgica se há citado como uma opción favorable para el tratamento de la recesión gengival moderada de Miller de classe I e II. Este artículo tiene como objetivo reportar um caso clínico de um paciente masculino de 43 años selecionado para el tratamento de la recesión gingival del diente 41. Luergo de la evolución clínica y radiográfica, concluímos que se trataba de uma recesión classe I de miller. Se decidió proceder quirúrgicamente com la cobertura radicular de este diente mediante la técnica de tunelización. Um mês después del procedimiento se observo cobertura radicular completa, ausência de sangrado al sondaje profundidad de sondaje de $3 \mathrm{~mm}$ y perfecta integración estética com los tejidos advacentes. A la vista del caso antes mencionado, es evidente que esta técnica presenta resultados muy predecibles cuando se indica u ejecuta correctamente, alcanzando asi um resultado muy estético.

Palabras clave: Retracción gingival; Cirugía Oral; Retracción gingival. 


\section{Introduction}

Gingival recession is nothing more than an apical displacement of the gingival margin, most often associated with tooth hypersensitivity and aesthetic complaints. They can be localized, affecting only one tooth, or generalized, affecting more than one tooth. (Saadoun, 2006)

As aesthetics is impaired, there is an increasing demand on the part of patients for periodontal plastic surgery techniques, which allows for harmonizing the smile with the covering of the recession.(Zuhr, 2014) (Tsourunakis, 2014)

There are numerous techniques already described in the literature for the treatment of gingival recessions, as the degree of complexity varies, the results may also vary. Therefore, it is extremely important that dentists choose the best technique for their various cases. (Saadoun, 2006) (Ribeiro, 2008)

Some basic variables can determine the choice of surgical technique, including: recession depth, amount of keratinized gingiva apical recession and gingival biotype. (Bouchard, 2001) (Dani, 2014).

Langer and Langer, in 1985, described the technique of subepithelial connective tissue graft (ETC) for the covering of isolated or multiple recessions. (Langer, 1985) Next, Raetzke published the envelope technique that differs from ETC.

(Raetzke, 1985) Some time later, in 1994, Allen, in a certain modification of Raetzke's technique, described the technique in tunnel or supraperiosteal envelope, also for the treatment of multiple adjacent recessions. (Allen, 1994)

Combining the techniques of Allen and Langer and Langer, Zabalegui combined tunneling techniques with ETC. (Zabalegui, 1999) And in 2002, Azzi described a tunnel between the mucosa and the periosteum, through sulcular incisions that included the papillae. (Azzi, 2002)

So, Zuhr et al. requested the use of specific surgical instruments for a perfect execution of the tunneling technique, to keep the papillae intact and the ETC exposed in the recessed area, with this portion being nourished by the lateral and apical areas of the graft. (Zuhr, 2007)

The tunneling technique is an alternative to traditional techniques. (Stimmelmay, 2011) Tunneling with ETC has shown good clinical results and very similar to RRC+ETC, with an excellent aesthetic result in terms of color and texture with the adjacente tissues. (Zuhr, 2014) (Stimmelmay, 2011) (Zuhr, 2014)

The use of correct instruments allows the dentist to handle tissue in an atraumatic way. (Miller, 1985) (Han, 2008) (Shanelec, 2003) And combined with the use of extremely thin sutures (6/0 or 7/0), it contributes to less tissue trauma, less scar tissue formation, rapid vascularization and better postoperative period. (Burkhardt, 2005)

The aim of this article is to report a clinical case carried out at the Inapós School Clinic, in Pouso Alegre, Mg. A surgical technique called tunneling to cover a gingival recession was performed on a 43-year-old male patient.

\section{Methodology}

This article is a clinical case report. The surgical tunneling technique was used to cover the gingival recession in the region of tooth 41 of a patient at the teaching clinic of Inapós - Pouso Alegre. The patient is Caucasian, 43 years old, without any systemic involvement. The microsurgical material used was the tunneling tool, for making the tunnel using the tunneling technique. The patient signed an informed consent form allowing the use of data, radiographs and photographs contained in the medical record for scientific publications or academic activities, as provided for in the Dental Code of Ethics. We are committed to ensuring the privacy and confidentiality of patient data, fully preserving the anonymity and image of the subject, as well as its non-stigmatization. In addition to not using the information and images to your detriment. The procedure is also in accordance with the rules established by those responsible for the Clinical Investigation and Ethics Committee. 


\section{Results}

A 43-year-old, healthy, non-smoking male patient attended the Inapós school clinic for treatment of the gingival recession present in tooth 41. After clinical and radiographic evaluation (Figure 1), the presence of class I gingival recession was observed of Miller (Figure 2).

Figure 1 - Radiographic image of tooth 41.

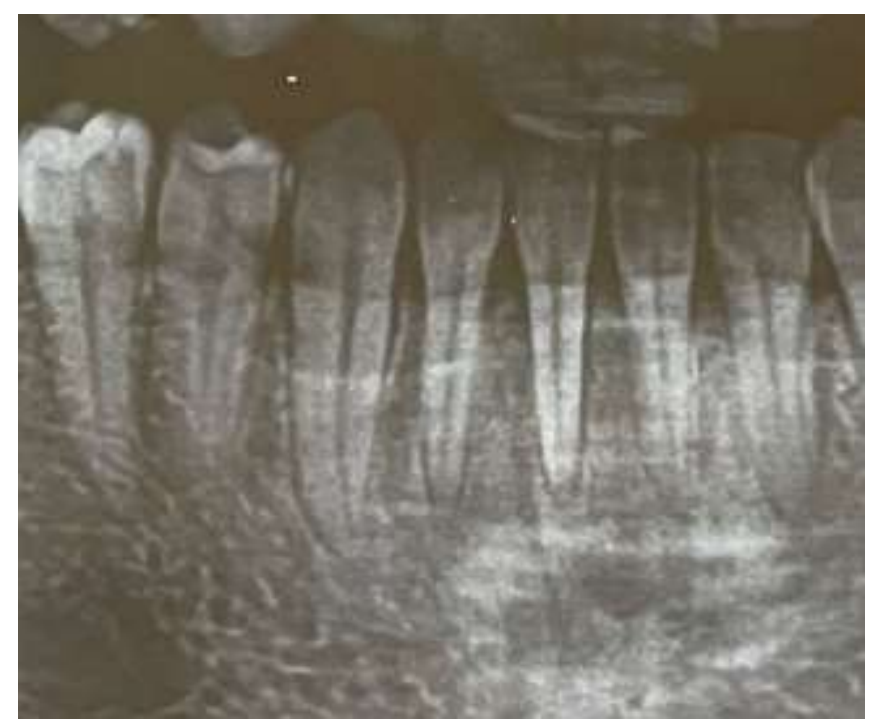

Source: Authors.

It is extremely important to observe the bone around element 41.

Figure 2 - Close-up view of the gingival recession of tooth 41 .

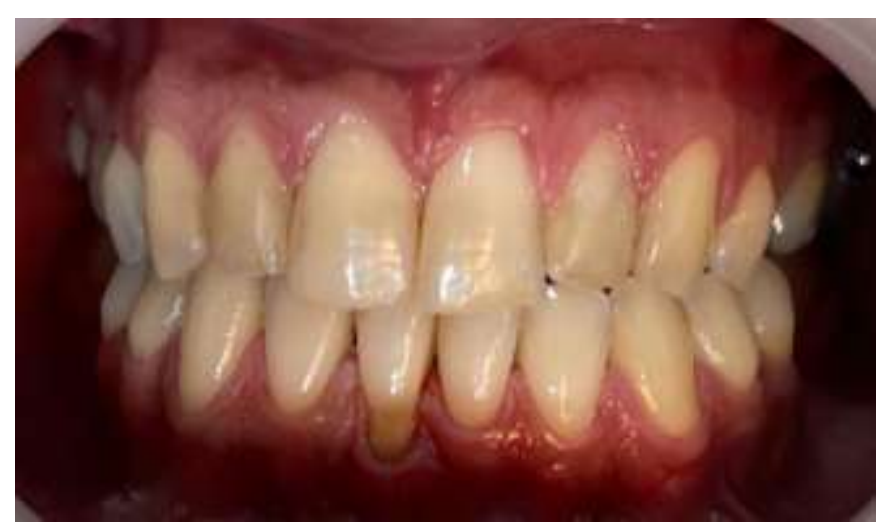

Source: Authors.

In this image, it is possible to clinically observe the Miller class I recession present in element 41.

It is possible to clearly observe the Miller class I recession in the 41st region.

In the first consultation, the patient received instructions on oral hygiene, together with a very well-made prophylaxis and a supragingival scaling of all quadrants. With no gingival inflammation at the site, it was decided to proceed with the covering of this tooth, using a tunneled ETC. 
Before starting the surgery, antisepsis was performed with $0.2 \%$ chlorhexidine gluconate for 1 minute and then bilateral mental anesthetic technique was performed with lidocaine (Figure 3). We started with scaling and root planing of the area in question, with a mini-five $1-2$ curette.

Figure 3 - Bilateral mental anesthetic technique with lidocaine.

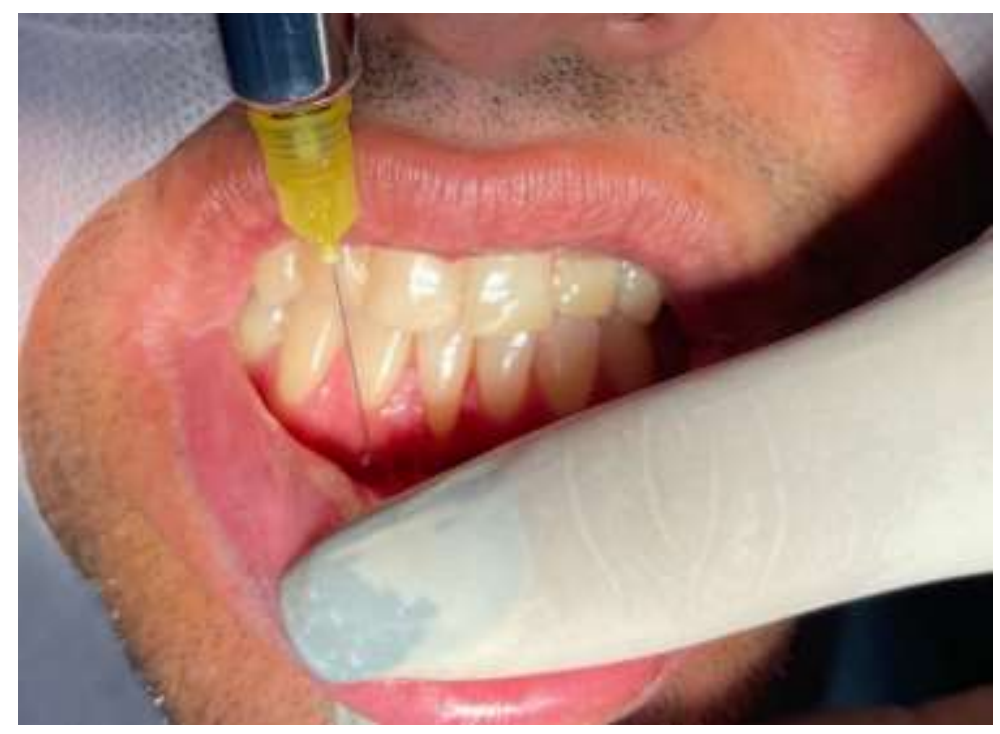

Source: Authors.

In the figure it is possible to observe the anesthetic technique called mentonian. When injected into the mental foramen, the solution diffuses through the mental canal, which is very short (3 to $6 \mathrm{~mm}$ ), and blocks the inferior alveolar nerve itself. Thus, the insensitivity of the anterior and premolar teeth, of its vestibular gingiva and of the skin and mucosa of the chin and lower lip is gained.

Microsurgical instruments (tunneling) were used for better tissue manipulation. (Figure 4).

Figure 4 - Surgical microinstrument kit.

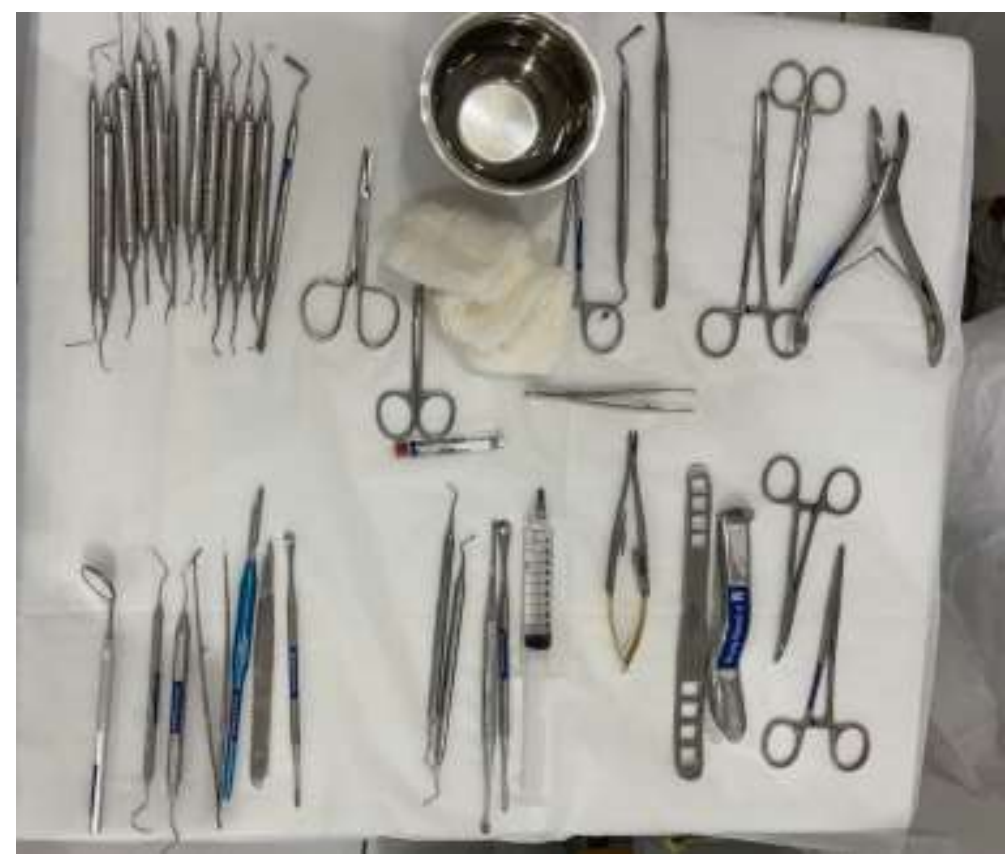

Source: Authors. 
It is worth noting the microsurgical materials contained in the surgical table in this case. The tunneling tool is an instrument indicated for minimally invasive surgeries.

Then, the procedure started with the preparation of the receiving area, through an intrasulcular incision with a $15 \mathrm{C}$ scalpel blade. (Figure 5).

Figure 5 - Intrasulcular incision with a $15 \mathrm{C}$ scalpel blade. The papillae remain intact.

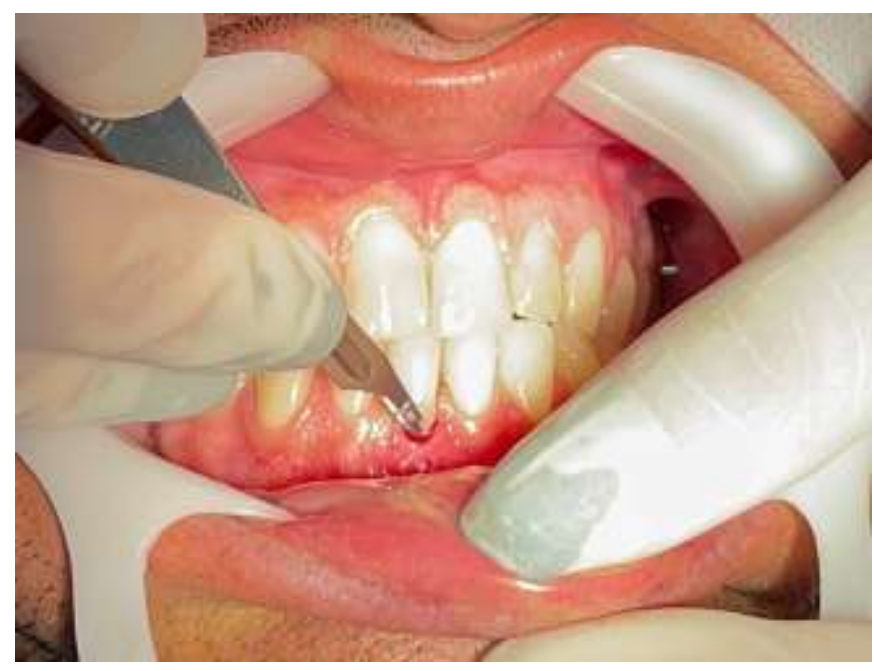

Source: Authors.

Scalpel blades are used for cutting skin and tissue in surgery. In this case, as shown in the image, it was decided to use a $15 \mathrm{c}$ blade for a less traumatic cut, as this is an aesthetic area.

Subsequently, a supraperiosteal tunnel is created, according to the modified technique by Zuhr et al. (Figure 6).

Figure 6 - Preparation of the tunnel with suitable instruments.

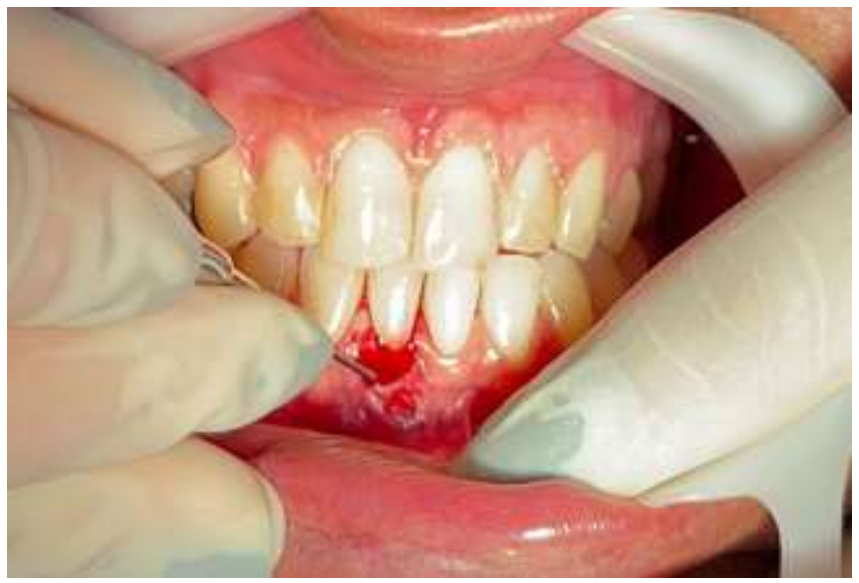

Source: Authors. papillae.

In the figure, it is possible to observe the work on the tunneling tool for making the tunnel, without compromising the

With the appropriate instruments, a partial-thickness flap was created, which extended apically beyond the mucogingival line and laterally one tooth beyond the recession. In the interdental area, the flap extended coronally to the base of the papillae, 
in order to allow its subsequent elevation. With the periodontal probe, it was verified if the tunnel was all in the same plane, in order to allow an easy sliding of the graft. (Figure 7).

Figure 7 - Tunnel prepared.

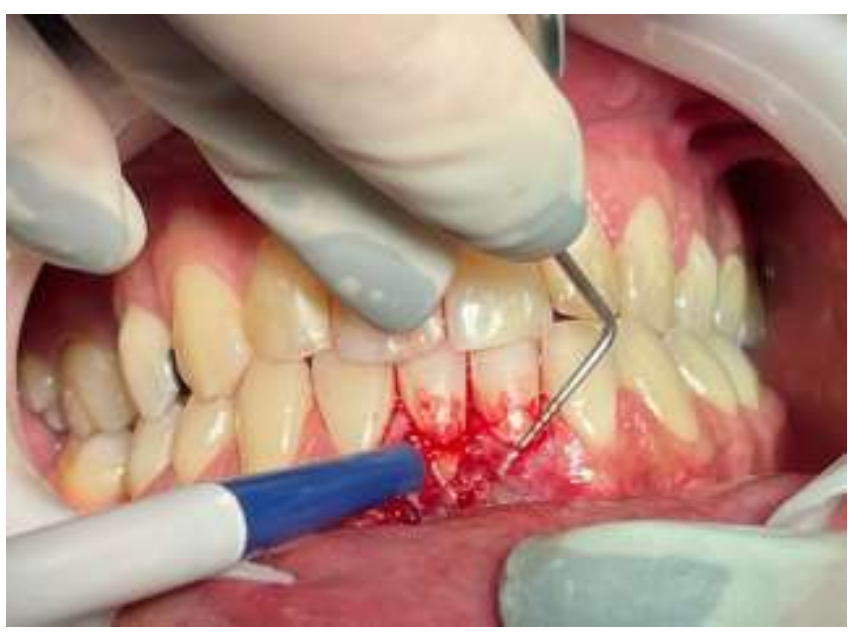

Source: Authors.

Right after the preparation of the tunnel, as shown in the figure, we check with a probe if the tissue is detached in the correct way and quantity to follow the surgery.

The palate was the donor area, after the greater palatal anesthetic technique, we collected an ETC measuring approximately $12 \mathrm{~mm}$ in length and $1 \mathrm{~mm}$ in thickness (Figure 8 ) through a single incision, $3 \mathrm{~mm}$ away from the gingival margin of the maxillary premolars. (Figure 9).

Figure 8 - Linear incision for removal of the connective tissue graft.

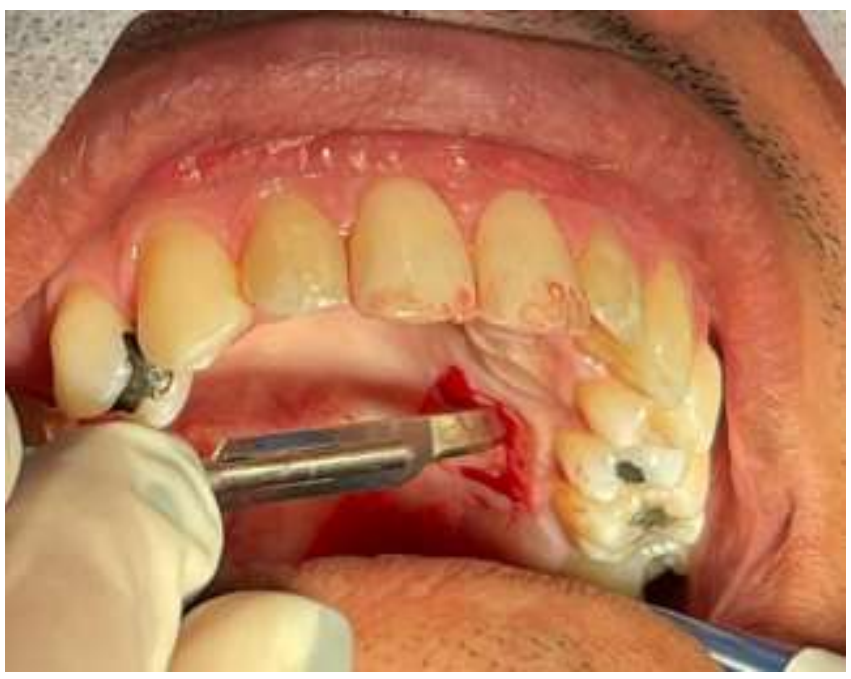

Source: Authors.

The graft was removed from the left side of the patient's palate, as shown in the figure. The chosen donor area was the palate due to its mucosal surface, resistance to contraction and its easy removal, which are advantages over other grafts. 
Figure 9 - Subepithelial connective tissue graft.

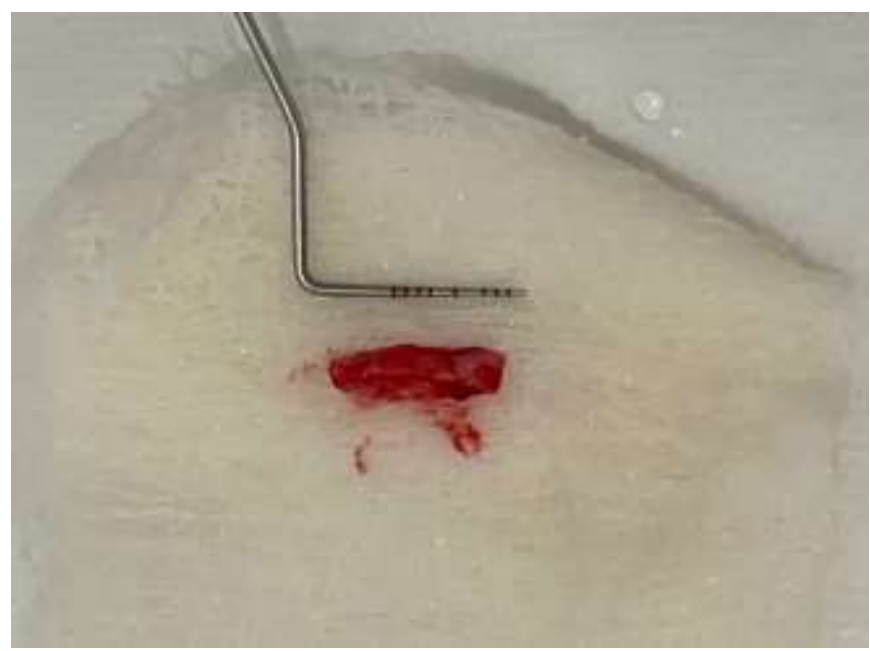

Source: Authors.

The graft is observed right after removal from its donor area. It is very important to keep him hydrated at all times.

The graft was guided through the tunnel, leaving a $1 \mathrm{~mm}$ carcass above the cementoenamel junction. And suture with 6-0 nylon thread was performed. (Figure 10). Subsequently, we suspended the tissue and attached the 6-0 nylon thread with composite resin to element 41 for better healing of the area. (Figure 11).

Figure 10 - Connective tissue graft positioned through the tunnel and sutured with 6-0 nylon thread.

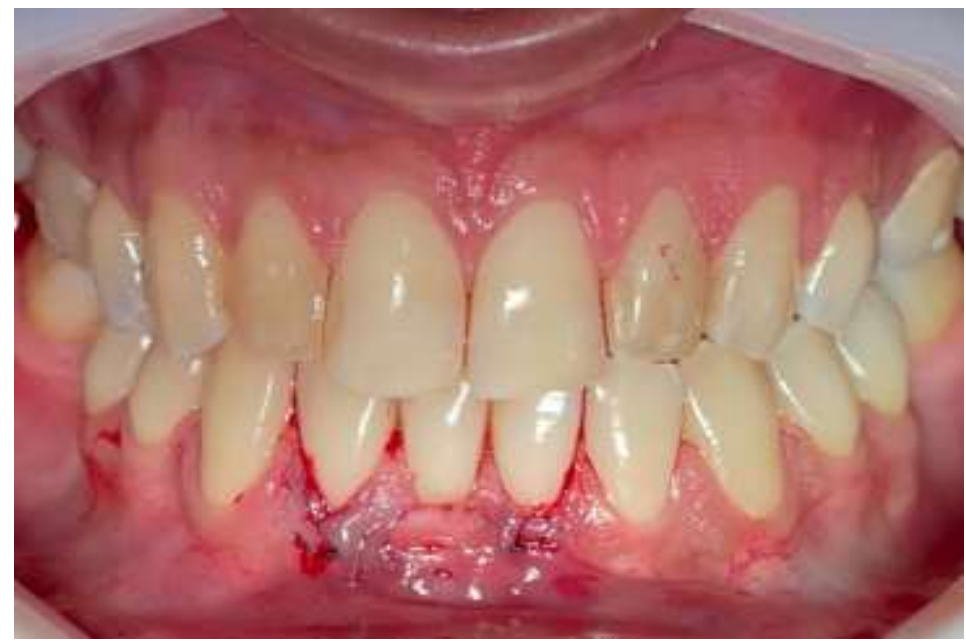

Source: Authors.

As it was clear in the figure, right after we placed the graft, the suture for its fixation was already performed. 
Figure 11 - Suspension of the tissue with a suture and later fixation on tooth 41 with composite resin.

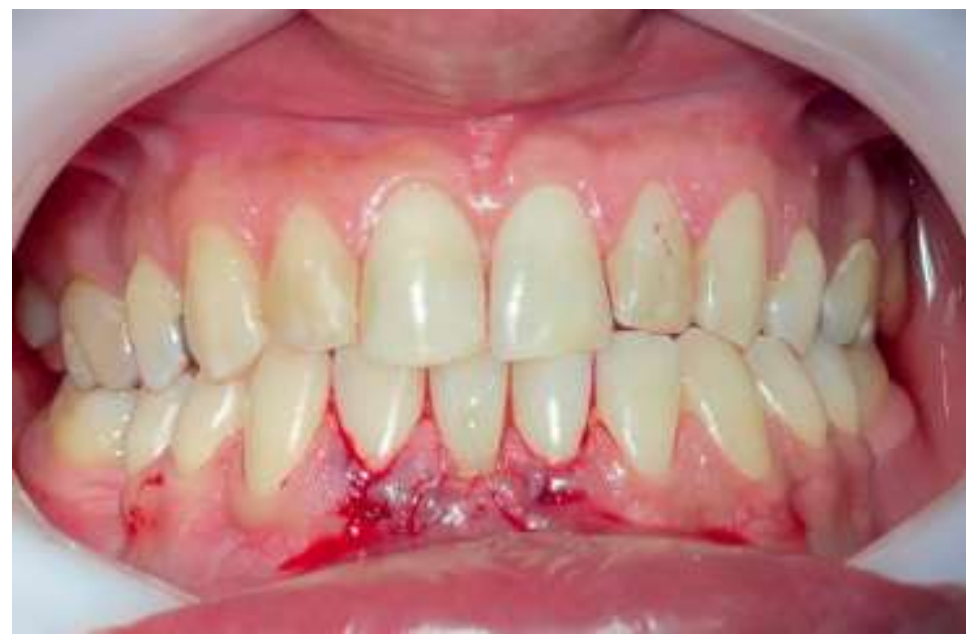

Source: Authors.

It is possible to observe the suture thread that was secured with composite resin in element 41 to further improve the adaptation and fixation of the graft in place.

In the donor region, the palate, we compressed a hemopon and fixed it with an X-shaped suture (Figure 12).

Figure 12 - X-shaped suture of the donor region.

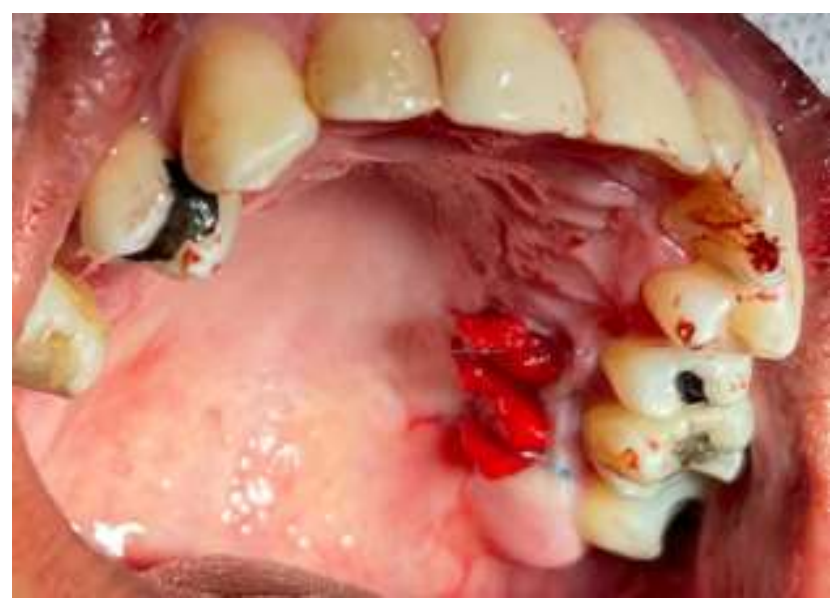

Source: Authors.

This figure shows the palate, the donor area, right after the suture.

After surgery, the patient was instructed not to brush the region. They were prescribed: $500 \mathrm{mg}$ amoxicillin, $4 \mathrm{mg}$ dexamethasone and $500 \mathrm{mg}$ acetaminophen.

After 7 days, suture removal from the donor site and CHX gel prophylaxis of the recipient site were performed. And after 15 days, the remaining sutures were removed.

\section{Discussion}

Tunneling is a surgical technique developed as a modification of the envelope technique 6 and the results in the literature confirm a good root recovery and increase in the quantity of keratinized gingiva. (Zuhr, 2014) (Ribeiro, 2008) (Stimmelmay, 2011) (Zuhr, 2014) (Chambrone, 2008) 
When we have great aesthetic demands in the treatment of multiple recesses with a depth less than or equal to $3 \mathrm{~mm}$, the tunneling technique may be at the option of choice. Because of this, it allows the preservation of the papillae, assuring a better blood supply from Enxerto, allowing to achieve excellent aesthetic results and will function for a long time. (Saadoun, 2006) (Dani, 2014) (Stimmelmay, 2011) (Salama, 2008) (Miller, 1985) (Chambrone, 2008)

For the prevention of any possible necrosis in the enxerto region, it is essential to ensure that there is no enxerto porção superior to 1-2 mm exposed fica, keeping most of the enxerto peeling the mucosa of the tunnel. (Han, 2008)

The microsurgical materials used, together with the well-executed technique, become beneficial in the reduction of technical trauma, contributing to a greater vascularization of the area, with better postoperative results. (Salama, 2008) (Miller, 1985) (Shanelec, 2003)

Tunneling appears as vantage: in the absence of discharge incisions, absence of significant alterations, non-positioning of the mucogengival line, maintenance of the depth of the vestibule (stimmelmay, 2011) (Stimmelmay, 2011), and protection of the position and height of the papillae. (Dani, 2014) (Salama, 2008) In the patient's perspective, in the absence of scar and aesthetic integration, they can also be valued the advantages. (Dani, 2014)

In return, a very sensitive technique is constituted, which must be performed by experienced dental surgeons and with specific instruments. (Zuhr, 2007) (Salama, 2008)

\section{Conclusion}

We conclude that the technique used in this case presents satisfactory and safe results, when performed by a dental professional, demonstrating an effective result from an aesthetic point of view, thus aiming to preserve the dental element in the mouth. Afterwards, it is necessary to follow the case for the next few months, in order to confirm a perfect healing of the region and the patient's esthetic approval.

\section{Acknowledgments}

To Professor Doctor Rafael de Aguiar Vilela Junior, who helped me and contributed to the development of the work. To Professor Dr. Márcio Américo Dias, an example of a professional, always solicitous and generous.

\section{References}

Saadoun, A. P. Current trends in gingival recession coverage part I: the tunnel connective tissue graft. Pract Proced Aesthet Dent, 18:433-40.

Zuhr, O., Rebele, S. F., Schneider, D., Jung, R. E., \& Hurzeler, M. B. Tunnel Technique with connective tissue graffiti versus coronally advanced flap with enamel matrix derivative for root coverage: A RCT using \#D digital methods. PartII: volumetric studies on healing dynamics and gingival dimensions. $J$ Clin Periodontol. 41:593-603.

Tsourunakis, I., Sweidan, C., Palaiologou, A. A., \& Maney, P. Coverage of isolated, severe gingival recession: A modified technique. Clin Adv in Periodontics. $4: 148-53$.

Ribeiro, F. S., Zandim, D. L., Pontes, A. E. F., Mantovani, R. V., \& Sampaio, J. E. C., Marcantonio, E. Tunnel technique with a surgical maneuver to increase the graft extension: Case report with a 3-year old follow-up. J Periodonthol. 79:753-8.

Bouchard, P., Malet, J., \& Borghetti, A. Decision-making in aesthetics: Root coverage revisited. Periodontology 2000. 27:97-120.

Dani, S., Dhage, A., \& Gundannavar, G. The pouch and tunnel technique for management of multiple gingival recession defects. $J$ Indian Soc Perio. 18:77680.

Langer, B., \& Langer, L. Subepithelial connective tissue graft technique for root coverage. J Periodonthol. 56:715-20.

Raetzke, P. B. Covering localized areas of root exposure using the envelope technique. J Periodonthol. 56:397-402.

Allen, A. L. Use of supraperiosteal envelope in soft tissue grafting for root coverage. I. Rationale and technique. Int $\mathrm{J}$ Periodontics Restorative Dent. 1994;14:216-7. 
Research, Society and Development, v. 10, n. 12, e107101220183, 2021

(CC BY 4.0) | ISSN 2525-3409 | DOI: http://dx.doi.org/10.33448/rsd-v10i12.20183

Zabalegui, I., Sicilia, A., Cambra, J., Gil, J., \& Sanz, M. Treatment of multiple gingival recessions with the subepithelial tunnel connective tissue graft: A clinical report. Int J Periodontics Restorative Dent. 19:471-9.

Azzi, R., Etienne, D., Takei, H., \& Fenech, P. Surgical thickening of the existing gingiva and reconstruction of interdental papillae around implant-supported restorations. Int J Periodontics Restorative Dent. 22:71-7.

Zühr, O., Fickl, S., Watchtel, H., Bolz, W., \& Hurzeler, M. B. Covering of gingival recessions with a modified microsurgical tunnel technique: case report. Int J Periodontics Restorative Dent. 27:456-63.

Stimmelmay, M., Allen, E., Gernet, W., Edelhoff, D., Beuer, F., Schlee, M., et al. Treatment of gingival recession in the anterior mandible using the tunnel technique and an epithelialized-subepithelial connective tissue graft-a case series combination. Int J Periodontics Restorative Dent. 31:164-73.

Salama, H., Salama, M., \& Garber, D. The tunnel technique in the periodontal plastic treatment of multiple adjacent gingival recession defects: A review. Inside Dentistry. 4:78-81.

Zühr, O., Rebele, S. F., Schneider, D., Jung, R. E., \& Hurzeler, M. B. Tunnel technique with connective tissue graft versus coronally advanced flap with enamel matrix derivative for root coverage: RCT using 3D digital methods. Part I: Clinical and patient-centered outcomes. J Clin Periodontol. 41:582-92.

Miller, P. D. Jr. A classification of marginal tissue recession. Int J Periodontics Restorative Dent. 5:8-13.

Han, J. S., John, V., Blanchard, S. B., Kowolik, M. J., \& Eckert, G. J. Changes in gingival dimensions following connective tissue grafts for root coverage: Comparison of two procedures. J Periodonthol. 79:1346-54.

Shanelec, D. A. Periodontal Microsurgery. J Esthet Restor Dent. (15):18-23.

Burkhardt, R., \& Lang, N. P. Coverage of localized gingival recessions: A comparison of micro- and macrosurgical techniques. J Clin Periodontol. 32:287-93.

Chambrone, L., Chambrone, D., Pustiglioni, F. E., Chambrone, L. A., \& Lima, L. A. Can subepithelial connective tissue grafts be considered the gold standard procedure in the treatment of Miller Class I and II recession-type defects? J Dent. 36:659-71.

Allen, E. Subpapillar continuous sling suture method for soft tissue grafting with the tunneling technique. Int J Periodontics Restorative Dent. 30:478-85. 